\title{
REVIEW \\ Sina Rauschenbach \\ Judentum für Christen: \\ Vermittlung und Selbstbehauptung Menasseh ben Israels in den gelehrten Debatten des 17. Jahrhunderts.
}

(Berlin: De Gruyter, 2012), vii + 344 pp.

David H. Price,

University of Illinois, Urbana-Champaign

Sina Rauschenbach's book, which is a revision of her 2010 Habilitationsschrift for the University of Constance, meticulously analyzes Menasseh ben Israel's strategies for mediating Jewish thought for Christians, mainly by comparing the Latin versions to the Spanish originals for several of his publications. She also offers a comprehensive and highly illuminating account of the Christian reception of Menasseh's works, an effort that is especially valuable for the works that pertain to Menasseh's England mission in the 1650s.

Menasseh ben Israel, the prolific Sephardic author and publisher, was read so avidly by Christian scholars that Cecil Roth fittingly dubbed him "an apostle to the gentiles." Initially, Menasseh's principal concern was to serve conversos returning to orthodoxy in the Netherlands and elsewhere. For that purpose, he established a publishing house in Amsterdam-the very first to print Hebrew there-that specialized in Bibles, prayer books and religious tracts. Soon, his press produced books for Ashkenazi communities as well. One of his own early writings in Spanish-the Conciliador of 1632-51-attracted a large readership among Christians, especially once its first volume was translated into Latin in 1633 by his friend Dionysius Vossius, son of the renowned scholar Gerardus Vossius. As Menasseh surely knew from his ever-expanding circle of Christian acquaintances, the Conciliador possessed great 
relevance to Christian biblical scholars since it attempted to reconcile apparent inconsistences in passages of the Hebrew Bible. Moreover, the book's methodology of compiling rabbinic and medieval Jewish commentary on problematic passages had the additional attraction of making a very large selection of Jewish scholarship easily available to Christians. Remarkably, Menasseh also included several Christian theologians among the authorities. The Latin translation of this work achieved a kind of celebrity status for him among Christian scholars from all over Europe. Thereafter, leading scholars of the age corresponded or conferred in person with the famous rabbi (Caspar Barlaeus, Robert Boyle, Jan Amos Comenius, Hugo Grotius, Isaac la Peyrère, Rembrandt, Petrus Serrarius, Antonio Vieira, and Vossius being among the many).

Following the success of Conciliador, Menasseh frequently conceptualized his theological tracts for simultaneous reception among Jews and Christians. In 1635 he published a study of biblical portrayals of creation in Latin only, De creatione problemata $X X X$. This tract clearly expresses specifically Jewish concepts of messianism, albeit concepts that were fascinating to Christian millenarians, yet also comments on a few theological doctrines, such as purgatory (which Menasseh concludes does not exist), that were relevant only to Christians. In De resurrectione mortuorum libri III (1536), which appeared in both Spanish and Latin, he treated a fierce controversy in contemporary Judaism, initiated by the tragic figure Uriel da Costa, that was also of interest to Christian theologians: the nature of the soul and of life after death. Subsequent works, also produced in Spanish and Latin versions, continued to connect Jewish and Christian theological concerns (De termino vitae and Dissertatio de fragilitate humana), entertaining such Christian questions as the doctrine of predestination (which he rejects) and original sin. More famously, in the $1640 \mathrm{~s}$, Menasseh became a significant source for new Christian speculation on the possibility that Native Americans descended from the lost tribes of Israel and that their ingathering would initiate the end of time. After Antonio de Montezinos reported finding a tribe adhering to "Jewish" 
practices in the Andes, Menasseh sent a French translation of Montezinos' account to the English millenarian John Dury. In his Miqwe Yisrael...Esperança de Israel (1650), a work immediately translated into Latin and, then, English, Menasseh printed and interpreted the report from a Jewish messianic perspective, even though his analysis was addressed to Christian readers. Owing to the keen interest of English millenarians, this ultimately set the stage for Menasseh's most significant intervention in the Christian world, his attempt to promote readmission of Jews to England under Oliver Cromwell's commonwealth. His famous mission to England in 1655 was the context for the composition of the Vindication of the Jews (originally published in Latin), his classic defense of Judaism.

Rauschenbach's study is a comprehensive assessment of Menasseh ben Israel's remarkable career with one important exception. The history of Sephardi returning to Judaism during Menasseh's generation is not a central interest of this book, which results in the relative neglect of a few major works, such as his Thesouro dos dinim (1645-7) and his Spanish translation of the Pentateuch (Humash o Cinco libros de la Ley Divina, 1655). This is also true for most of the Hebrew publications, especially the Bible in Hebrew, as well as his editions of the Talmud. I might add that all of these works were also certainly intended partially for Christian scholars, some of which were even produced with Christian patronage. Rauschenbach mentions them, but does not undertake any discussions of these important efforts. The treatment of the English mission offers an exceedingly valuable textual history of his intervention, but it does not attempt to explain or appreciate Menasseh ben Israel's long-term contributions to the successful resettlement of Jews to England. Rauschenbach seems to view the effort as having been entirely fruitless since, after all, Menasseh was unable to negotiate a charter for resettlement. Yet she does not directly challenge the portrayals advanced by other scholars (Roth and David Katz, for example) who see historical advantages arising from his intervention. A fresh assessment of the relative significance of 
religious (especially millenarian) and economic motivations of the English, a point of disagreement in the historiography on the Whitehall deliberations on readmission, would also have been useful.

These are very minor issues, in fact, matters arguably beyond the scope of this outstanding and insightful study. In the event that German is an impediment, the author has also published a succinct English version of the key elements of Chapters 2, 3, 4, and 5 in Jewish Quarterly Review 102 (2012), 561-88: "Mediating Jewish Knowledge: Menasseh ben Israel and the Christian Respublica Litteraria." 